\title{
(6) OPEN ACCESS \\ Racecadotril for acute diarrhoea in children: systematic review and meta-analyses
}

\author{
Morris Gordon, ${ }^{1,2}$ Anthony Akobeng 3,4
}

\begin{abstract}
- Additional material is published online only. To view please visit the journal online (http://dx.doi.org/10.1136/ archdischild-2015-309676).

${ }^{1}$ Department of Medical Education, Blackpool Victoria Hospital, Blackpool, UK ${ }^{2}$ School of Medicine and Dentistry, University of Central Lancashire, Preston, UK ${ }^{3}$ Sidra Medical \& Research Center, Doha, Qatar ${ }^{4}$ Royal Manchester Children's Hospital, Manchester Academic Health Centre, University of Manchester, Manchester, UK
\end{abstract}

\section{Correspondence to} Dr Morris Gordon, HA106, Harrington Building, School of Medicine and Dentistry, University of Central Lancashire, Preston PR1 2HE, UK; morris@betterprescribing. com

Received 1 September 2015 Revised 24 November 2015 Accepted 25 November 2015 Published Online First 29 December 2015

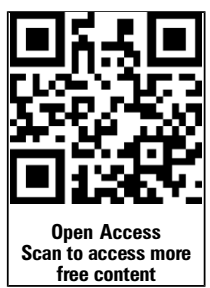

CrossMark

To cite: Gordon $\mathrm{M}$, Akobeng A. Arch Dis Child 2016;101:234-240.

\section{ABSTRACT \\ Objective Racecadotril is an antisecretory agent that} can prevent fluid/electrolyte depletion from the bowel as a result of acute diarrhoea without affecting intestinal motility. An up-to-date systematic review is indicated to summarise the evidence on racecadotril for the treatment of acute diarrhoea in children.

Design A Cochrane format systematic review of randomised controlled trials (RCTs). Data extraction and assessment of methodological quality were performed independently by two reviewers. Methodological quality was assessed using the Cochrane risk of bias tool.

Patients Children with acute diarrhoea, as defined by the primary studies.

Interventions RCTs comparing racecadotril with placebo or other interventions.

Main outcome measurs Duration of illness, stool output/volume and adverse events.

Results Seven RCTs were included, five comparing racecadotril with placebo or no intervention, one with pectin/kaolin and one with loperamide. Moderate to high risk of bias was present in all studies. There was no significant difference in efficacy or adverse events between racecadotril and loperamide. A meta-analysis of three studies with 642 participants showed significantly shorter duration of symptoms with racecadotril compared with placebo (mean difference $-53.48 \mathrm{~h}, 95 \% \mathrm{Cl}$ -65.64 to -41.33 ). A meta-analysis of five studies with 949 participants showed no significant difference in adverse events between racecadotril and placebo (risk ratio $0.99,95 \% \mathrm{Cl} 0.73$ to 1.34 ).

Conclusions There is some evidence that racecadotril is more effective than placebo or no intervention in reducing the duration of illness and stool output in children with acute diarrhoea. However, the overall quality of the evidence is limited due to sparse data, heterogeneity and risk of bias. Racecadotril appears to be safe and well tolerated.

\section{BACKGROUND}

Acute diarrhoea, with or without vomiting, constitutes approximately $14 \%$ of presentations to paediatric A\&E departments every year in the UK, leading to over 50000 acute admissions annually in England alone. ${ }^{2}$ Acute watery diarrhoea continues to cause significant morbidity in infants and young children both in developing ${ }^{3}$ and developed ${ }^{4}$ countries, despite advances in oral rehydration therapy and newly developed vaccines. As a result, this condition remains a substantial financial burden to the NHS at both secondary and tertiary level care. ${ }^{2}$

Although diseases leading to an acute diarrhoeal illness are often self-limiting, shortening of the illness duration can have significant benefits with

\section{What is already known on this topic}

- Oral rehydration solution (ORS) is the mainstay of treatment for acute diarrhoea in children.

- Racecadotril is an antisecretory agent with a different mechanism of action from existing antidiarrhoeal agents that can be used with ORS to prevent fluid and electrolyte depletion.

- Previous reviews are limited by age and significant methodological flaws.

\section{What this study adds}

- The evidence synthesised suggests that the addition of racecadotril to ORS can reduce the length of symptoms as well as the number and volume of stools passed during the illness.

- The use of racecadotril appears self and well tolerated in children with acute diarrhoea.

- The evidence base is generally of low quality and at high risk of bias.

regard to hydration and subsequent morbidity. Oral rehydration therapy, although still underused in some areas, ${ }^{5}$ has become the foundation during an acute diarrhoeal illness although, increasingly, $\mu$-opioid receptor agonists have become more popular in certain situations. ${ }^{6}$ Racecadotril is an antisecretory agent with a different mechanism of action from existing antidiarrhoeal agents. It functions by selective inhibition of the enzyme neutral endopeptidase (also known as enkephalinase), a cell membrane peptidase enzyme found most commonly on the epithelium of the small intestine. ${ }^{7}$ The enzyme neutral endopeptidase degrades endogenous enkephalins in the intestinal mucosa which normally exhibit pro-absorptive and antisecretory properties. Racecadotril therefore aims to promote these antisecretory properties by prolonging the presence of the enkephalins through the inhibition of neutral endopeptidase. Ultimately, the hypersecretion of water and electrolytes is reduced without affecting intestinal motility/transit.

The main aim of treatment with racecadotril is to prevent fluid/electrolyte depletion from the bowel as a result of acute diarrhoea. The drug should be used alongside oral rehydration solution (ORS) as recommended by the National Institute of Health and Care Excellence (NICE) clinical guideline CG84 in children aged $>3$ months, as per licensing regulations. The treatment should be started 
following three episodes of watery diarrhoea in a $24 \mathrm{~h}$ period, until two normal stools have been produced. The product should be used for a maximum of 7 days.

The intervention with racecadotril aims to reduce symptoms of acute diarrhoea within the first $24 \mathrm{~h}$ of treatment by reducing stool frequency without affecting intestinal motility. Side effects of abdominal pain, bloating and rebound constipation, which occur with other well-known antidiarrhoeal agents, would not be expected with this treatment.

Racecadotril was first licensed in France in 1992 but has only been licensed and marketed since 2013 for use in children within the UK. Although there have been previously published reviews of the literature regarding racecadotril that included some meta-analysis, there are some clear limitations to this work. A review from 2007 is now significantly out of date with just three studies included. ${ }^{8}$ A review from 2011 has significant methodological flaws with one of the included studies not a randomised controlled trial (RCT) and a further study written by one of the review authors who would not provide more methodological data when requested. ${ }^{9}$ Additionally, neither of these reviews aligned themselves with the internationally recognised Cochrane standard for evidence synthesis. An up-to-date systematic review using the Cochrane Collaboration format is therefore indicated to summarise the current evidence on the efficacy and safety of racecadotril for the treatment of acute diarrhoea in children.

\section{METHODS}

The objectives of this review were to evaluate the efficacy and safety of racecadotril for the treatment of acute diarrhoea in children. A full protocol for the study was completed by the authors prior to commencement of the study and is available on request.

\section{Criteria for considering studies for this review}

RCTs were included in this systematic review. Participants were aged 3 months to 18 years with a diagnosis of acute diarrhoea (defined as three or more episodes of watery diarrhoea in a $24 \mathrm{~h}$ period within the last $72 \mathrm{~h}$ ). Studies compared racecadotril with another intervention or placebo, with all preparations and dosing regimens considered. Studies could give ORS to both groups, as this is the recommended administration method for racecadotril. The primary outcome measure for the studies was the total duration of diarrhoeal illness in days, as defined by the initial inclusion criteria. Secondary outcomes included: number of diarrhoeal episodes occurring per day at $48 \mathrm{~h}$ following treatment, duration of time taken for resolution of symptoms, stool output in $\mathrm{kg}$ per day in first $48 \mathrm{~h}$ after treatment, use of concomitant or alternative therapies such as other antidiarrhoeal agents, need for hospital admission, duration of hospital stay if admitted as inpatient and occurrence of any adverse events.

\section{Search methods for identification of studies}

Electronic searches (search strategy not limited by language) were completed of MEDLINE (1966 to 23 February 2015; National Library of Medicine, Bethesda, USA), EMBASE (1974 to 23 February 2015; Elsevier Science, New York, USA), Cochrane Central Register of Controlled Trials and Cochrane Inflammatory Bowel Disease and Functional Bowel Disorder Group Specialized Trials Register. The search strategy is shown in online supplementary appendix 1.

Similar search strategies, modified appropriately and using the same keywords, were used to search the other electronic databases listed above. There is some evidence that data from abstracts can be inconsistent with data in published articles. ${ }^{10}$ Therefore, relevant citations published in abstract form that met

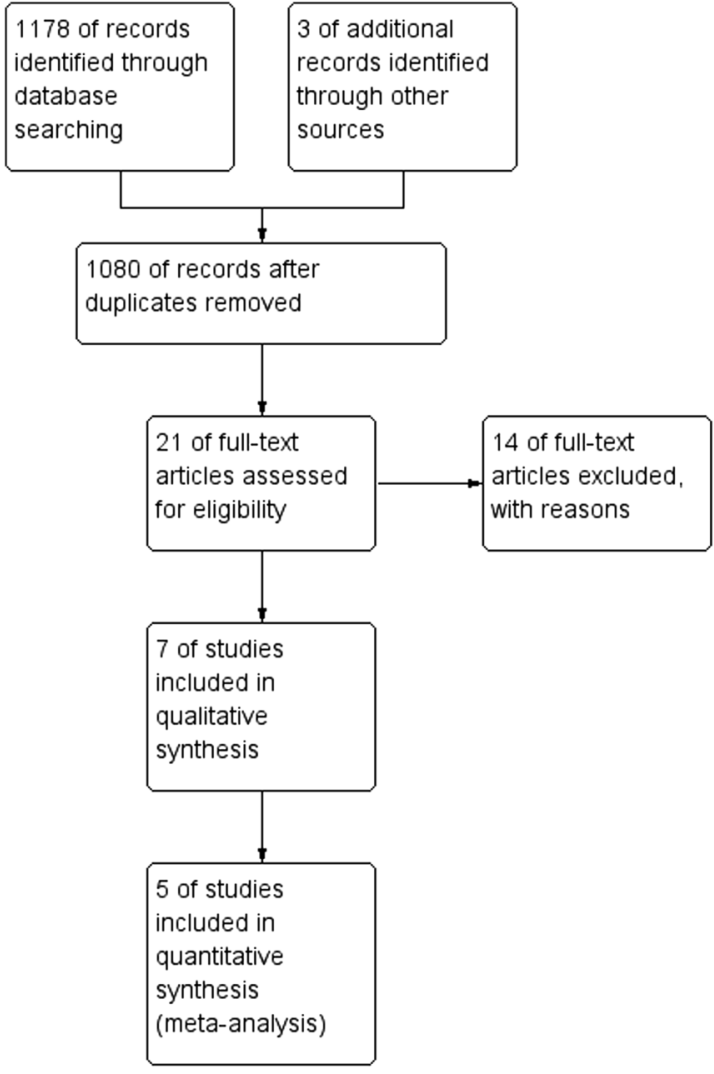

Figure 1 Flow diagram for search.

the inclusion criteria were only considered if the author could offer sufficient data regarding risk of bias and outcomes.

The references of all identified studies were inspected for more trials. Leaders in the field were contacted to try to identify other studies. Finally, the manufacturers of racecadotril were contacted for additional data. Unpublished studies were considered if they offered appropriate methodological and quality data.

\section{Data collection and analysis}

All identified abstracts and results from searches were reviewed by the authors. If the reference appeared relevant, a full copy of

Table 1 Excluded papers with reasons

\begin{tabular}{|c|c|}
\hline Excluded paper & Reason \\
\hline Alam et $a l^{13}$ & Adult RCT \\
\hline Alvarez Calatayud et al ${ }^{14}$ & Not RCT \\
\hline Cojocaru et al ${ }^{15}$ & Not randomised trial (alternate patient entry) \\
\hline Guarino et $a l^{16}$ & Review article \\
\hline Huighebaert et al ${ }^{7}$ & Review article \\
\hline Lehert et al ${ }^{9}$ & Review and meta-analysis \\
\hline Mehta et $a l^{18}$ & Not RCT \\
\hline Pieścik-Lech et al ${ }^{19}$ & Review article \\
\hline $\operatorname{Rao}^{20}$ & Not RCT \\
\hline Rautenberg et $a l^{11}$ & Not RCT \\
\hline Tebruegge $^{22}$ & Review article discussing another trial \\
\hline Tormo et $a l^{23}$ & Review article \\
\hline Savitha ${ }^{24}$ & $\begin{array}{l}\text { Abstract study, never published in full, author } \\
\text { contacted and responded but could not supply } \\
\text { further data to judge inclusion }\end{array}$ \\
\hline Szajewska et al ${ }^{8}$ & Previous systematic review \\
\hline
\end{tabular}


Table 2 Characteristics of included studies and risk of bias

\begin{tabular}{|c|c|c|c|c|c|c|c|c|c|c|c|c|}
\hline \multirow[b]{2}{*}{ Study } & \multirow[b]{2}{*}{ Year } & \multirow[b]{2}{*}{ No } & \multirow[b]{2}{*}{ Age } & \multirow[b]{2}{*}{$\begin{array}{l}\text { Racecaodotril } \\
\text { regimen }^{1}\end{array}$} & \multirow[b]{2}{*}{$\begin{array}{l}\text { Control } \\
\text { agent }^{1}\end{array}$} & \multirow[b]{2}{*}{ Context } & \multicolumn{6}{|l|}{ Risk of bias } \\
\hline & & & & & & & Randomisation & $\begin{array}{l}\text { Allocation } \\
\text { Concealment }\end{array}$ & Blinding & $\begin{array}{l}\text { Incomplete } \\
\text { outcomes }\end{array}$ & $\begin{array}{l}\text { Selective } \\
\text { reporting }\end{array}$ & Other \\
\hline Cézard et $a l^{25}$ & 2001 & 172 & 3 months -4 years & $\begin{array}{l}1.5 \mathrm{mg} / \mathrm{kg} \\
\text { administered orally } \\
3 \text { times daily }\end{array}$ & Placebo & $\begin{array}{l}\text { Inpatient, } 13 \\
\text { separate French } \\
\text { hospitals }\end{array}$ & $\begin{array}{l}\text { Stated randomised } \\
\text { but not method } \\
\text { given }\end{array}$ & Not mentioned & $\begin{array}{l}\text { Double } \\
\text { blinded }\end{array}$ & Low risk & $\begin{array}{l}\text { All appropriate } \\
\text { outcome data }\end{array}$ & $\begin{array}{l}\text { Involvement with } \\
\text { pharma not clear, many } \\
\text { recruited patients did not } \\
\text { meet inclusion }\end{array}$ \\
\hline $\begin{array}{l}\text { Gutiérrez-Castrellón } \\
\text { et } a^{26}\end{array}$ & 2010 & 280 & 1 month-2 years & $\begin{array}{l}1.5 \mathrm{mg} / \mathrm{kg} \\
\text { administered orally } \\
3 \text { times daily }\end{array}$ & Placebo & $\begin{array}{l}\text { Inpatient, } \\
\text { Mexico }\end{array}$ & Computer generated & $\begin{array}{l}\text { Central } \\
\text { allocation }\end{array}$ & $\begin{array}{l}\text { Double } \\
\text { blinded }\end{array}$ & Low risk & $\begin{array}{l}\text { All appropriate } \\
\text { outcome data }\end{array}$ & $\begin{array}{l}\text { Authors confirm no drug } \\
\text { company involvement }\end{array}$ \\
\hline $\begin{array}{l}\text { Gutiérrez-Castrellón } \\
\text { et al }{ }^{26}\end{array}$ & 2010 & 184 & 1 month-2 years & $\begin{array}{l}1.5 \mathrm{mg} / \mathrm{kg} \\
\text { administered orally } \\
3 \text { times daily }\end{array}$ & Placebo & $\begin{array}{l}\text { Outpatient, } \\
\text { Mexico }\end{array}$ & Computer generated & $\begin{array}{l}\text { Central } \\
\text { allocation }\end{array}$ & $\begin{array}{l}\text { Double } \\
\text { blinded }\end{array}$ & Low risk & $\begin{array}{l}\text { All appropriate } \\
\text { outcome data }\end{array}$ & $\begin{array}{l}\text { Authors confirm no drug } \\
\text { company involvement }\end{array}$ \\
\hline Salazar Lindo et $\mathrm{al}^{27}$ & 2000 & 135 & 3-35 months & $\begin{array}{l}1.5 \mathrm{mg} / \mathrm{kg} \\
\text { administered orally } \\
3 \text { times daily }\end{array}$ & Placebo & Inpatient, Peru & $\begin{array}{l}\text { Stated randomised } \\
\text { but not method } \\
\text { given }\end{array}$ & Not mentioned & $\begin{array}{l}\text { Double } \\
\text { blinded }\end{array}$ & Low risk & $\begin{array}{l}\text { All appropriate } \\
\text { outcome data }\end{array}$ & $\begin{array}{l}\text { Authors confirm no drug } \\
\text { company involvement }\end{array}$ \\
\hline Santos et $a^{28}$ & 2009 & 189 & $3-36$ months & $\begin{array}{l}1.5 \mathrm{mg} / \mathrm{kg} \\
\text { administered orally } \\
3 \text { times daily }\end{array}$ & Placebo & $\begin{array}{l}\text { Outpatient, } \\
\text { single centre, } \\
\text { Spain }\end{array}$ & Computer generated & $\begin{array}{l}\text { Not successfully } \\
\text { concealed }\end{array}$ & Open label & $\begin{array}{l}\text { One patient's } \\
\text { details missing }\end{array}$ & $\begin{array}{l}\text { All appropriate } \\
\text { outcome data }\end{array}$ & $\begin{array}{l}\text { Authors confirm no drug } \\
\text { company involvement, } \\
\text { except in initial design }\end{array}$ \\
\hline $\begin{array}{l}\text { Melendez Garcia } \\
\text { et } a^{29}\end{array}$ & 2007 & 50 & 3-71 months & Not specified & Kaolin/pectin & $\begin{array}{l}\text { Outpatient, } \\
\text { Guatemala }\end{array}$ & $\begin{array}{l}\text { Stated randomised } \\
\text { but not method } \\
\text { given }\end{array}$ & Not mentioned & $\begin{array}{l}\text { Unclear } \\
\text { how } \\
\text { blinded }\end{array}$ & Not complete & $\begin{array}{l}\text { No side effect } \\
\text { data }\end{array}$ & None apparent \\
\hline Turck et $a l^{30}$ & 1999 & 102 & $2-10$ years & $\begin{array}{l}1.5 \mathrm{mg} / \mathrm{kg} \\
\text { administered orally } \\
3 \text { times daily }\end{array}$ & $\begin{array}{l}0.03 \mathrm{mg} / \mathrm{kg} \\
\text { loperamide }\end{array}$ & $\begin{array}{l}\text { Outpatient, } \\
\text { multiple French } \\
\text { centres }\end{array}$ & $\begin{array}{l}\text { Stated randomised } \\
\text { but not method } \\
\text { given }\end{array}$ & Not mentioned & $\begin{array}{l}\text { Double } \\
\text { blinded }\end{array}$ & Low risk & $\begin{array}{l}\text { All appropriate } \\
\text { outcome data }\end{array}$ & None apparent \\
\hline
\end{tabular}




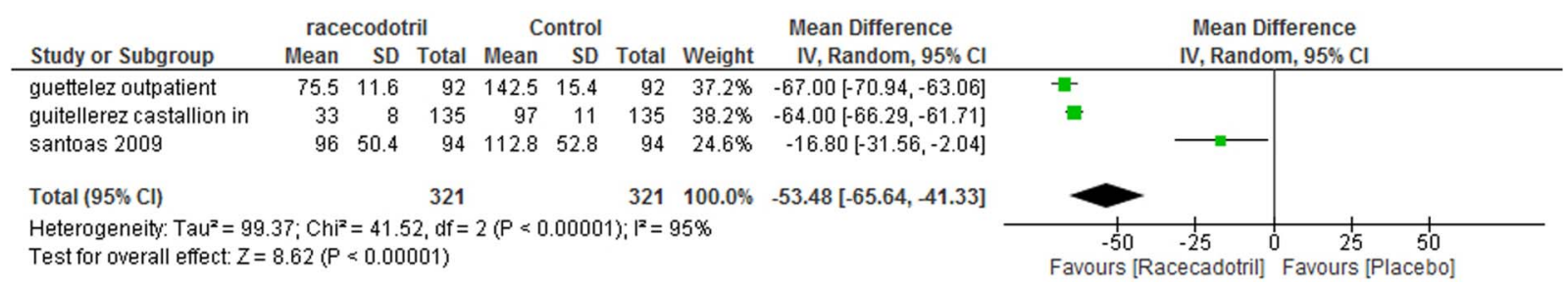

Figure 2 Forest plot of duration of diarrhoeal symptoms, racecadotril versus placebo.

the study was obtained. After reading the full texts, each author independently assessed the eligibility of all trials identified based on the inclusion criteria above. Disagreement among authors was discussed and agreement reached by consensus. If the data to judge inclusion were unclear, attempts were made to contact the authors.

A data extraction form was developed and piloted to extract information on relevant features and results of all primary and secondary outcomes of included studies. The two reviewers separately extracted and recorded data on the predefined checklist, with disagreement discussed and consensus reached.

The risk of bias of selected trials was assessed independently by the authors using the Cochrane risk of bias tool, ${ }^{11}$ with disagreement once again resolved by reaching consensus. Study authors were contacted for further information when insufficient information was offered to judge risk of bias or data were missing for primary outcomes.

Analysis was completed using Revman (Review Manager 5.2, V.5.2.9, The Nordic Cochrane Centre, The Cochrane Collaboration, Copenhagen, 2012). The primary outcometotal duration of diarrhoeal illness-was assessed using the mean difference (MD) with 95\% CI. The secondary outcomes were assessed by calculating the risk ratio (RR) and $95 \% \mathrm{CI}$ or the MD with 95\% CI, as indicated. The authors of included studies were again contacted to supply any missing data.

Heterogeneity among trial results was assessed by inspection of graphical presentations and by calculating the $\chi^{2}$ test of heterogeneity (a p value of 0.10 was regarded as statistically significant). We also used the $\mathrm{I}^{2}$ statistic to quantity the effect of heterogeneity. ${ }^{12} \mathrm{~A}$ random-effects model was used, with a sensitivity analysis with the fixed-effects model, to identify differences in results that would suggest heterogeneity.

\section{RESULTS}

Description of studies

The electronic database search identified 1178 studies that were screened for inclusion. Of these, 21 studies were judged to be potentially relevant and subjected to full text review (figure 1). Experts were contacted, but no extra reports were received and no further studies were identified from drug companies.

Fourteen reports were excluded for failing to meet the inclusion criteria (table 1). One was an abstract with insufficient data to judge inclusion, one was an adult RCT, five were studies that were not RCTs and seven were review articles or opinion pieces. Of particular note, three of these 14 studies were included in a previously published meta-analysis. ${ }^{9}$ One study was only published in this existing meta-analysis and did not offer appropriate information to judge inclusion. ${ }^{24}$ The author was contacted but was not able to offer further information so the study was excluded. Two further studies were not randomised ${ }^{14}{ }^{15}$ (one was published in Spanish and when translated was not random and one used alternate assignment into each group, an inappropriate method of randomisation).

Six reports of seven studies satisfied the inclusion criteria and were included in the review (table 2). Five studies compared racecadotril with placebo. One of these reports described two studies, an inpatient and an outpatient study. ${ }^{26}$ The author was contacted and was able to offer sufficient data to allow the studies to be analysed separately. One study compared racecadotril with loperamide and one study compared racecadotril with kaolin. The total number of participants in the seven studies was 1112. All participants were children between 1 month and 10 years of age with acute diarrhoea.

\section{Risk of bias of included studies}

Three studies were rated as low risk for random sequence generation (selection bias) because these studies employed computergenerated randomisation. The remaining studies described themselves as randomised but, with no further details given or available from authors, were rated as unclear risk of bias.

Two studies were rated as low risk of bias for allocation concealment (selection bias). Four studies were rated as unclear risk of bias for allocation concealment as the methods were not clearly described in the manuscripts. One study described a method that did not ensure allocation concealment and so was rated as high risk of bias. ${ }^{29}$

Five studies were double-blinded and were judged to be at low risk of bias for blinding of participants and personnel (performance bias). One study described itself as blinded, but gave no further details so was rated as unclear risk of bias. One study was open-label and judged to be at high risk of bias for blinding of participants and personnel.

Five studies reported full and appropriate data and satisfactorily documented withdrawals and dropouts and were therefore

\begin{tabular}{|c|c|c|c|c|c|c|c|c|c|c|c|c|c|}
\hline \multirow[b]{2}{*}{ Study or Subgroup } & \multicolumn{3}{|c|}{ racecodotril } & \multicolumn{3}{|c|}{ Placebo } & \multicolumn{3}{|c|}{ Mean Difference } & \multirow{2}{*}{\multicolumn{3}{|c|}{$\begin{array}{c}\text { Mean Difference } \\
\text { IV, Random, } 95 \% \mathrm{Cl}\end{array}$}} & \\
\hline & Mean & SD & Total & Mean & SD & Total & Weight & IV, Random, $95 \% \mathrm{Cl}$ & & & & & \\
\hline guitellerez castallion in & 176 & 24 & 135 & 398 & 27 & 135 & $50.0 \%$ & $-222.00[-228.09,-215.91]$ & & $\square$ & & & \\
\hline salazar lindo 2001 & 92 & 12 & 68 & 170 & 15 & 67 & $50.0 \%$ & $-78.00[-82.59,-73.41]$ & & $\mathbf{\square}$ & & & \\
\hline Total $(95 \% \mathrm{Cl})$ & & & 203 & & & 202 & $100.0 \%$ & $-149.99[-291.10,-8.87]$ & & & & & \\
\hline $\begin{array}{l}\text { Heterogeneity: } \operatorname{Tau}^{2}=10 \\
\text { Test for overall effect: } Z\end{array}$ & $\begin{array}{l}60.43 \\
2.08(P\end{array}$ & $\begin{array}{l}\mathrm{h}^{2}= \\
0.04)\end{array}$ & 1369.3 & $9, d f=1$ & $(P<$ & 0.000 & $01) ;\left.\right|^{2}=1$ & $00 \%$ & -1000 & $\begin{array}{l}-500 \\
\text { Irs [Racecadotril] }\end{array}$ & Favours [P & $\begin{array}{l}500 \\
\text { laceb }\end{array}$ & 1000 \\
\hline
\end{tabular}

Figure 3 Forest plot of stool output in the first $48 \mathrm{~h}$, racecadotril versus placebo. 


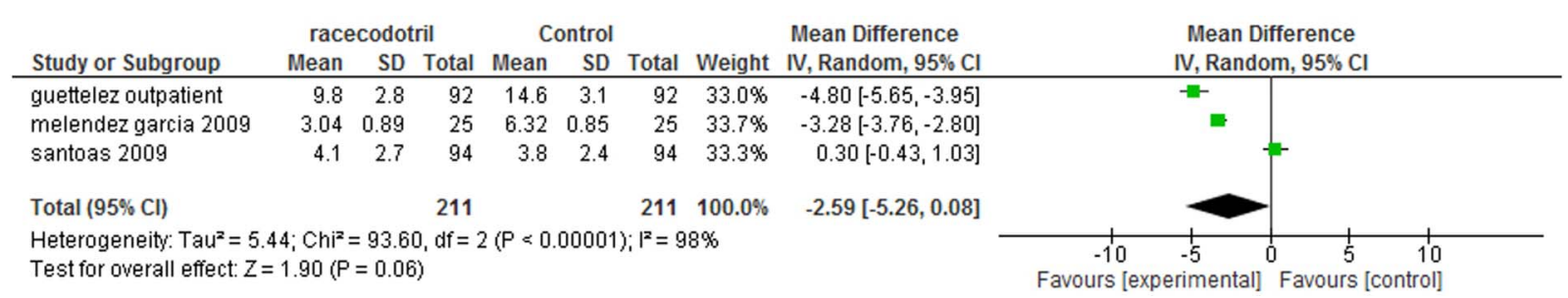

Figure 4 Forest plot of stool output per day at $48 \mathrm{~h}$, racecadotril versus placebo.

judged to be at low risk of bias for incomplete outcome data (attrition bias) and six were judged as low risk for selective reporting (reporting bias). Two studies did not record full data for all patients and were judged high risk of bias for attrition bias. One study did not offer outcome data regarding side effects and so was judged at high risk for reporting bias.

Finally, all but one study were judged to be at low risk for other sources of bias. This study had an affiliation with a pharmaceutical company, but details of the extent of involvement were unavailable and so it was judged to be at unclear risk of bias. Details are summarised in table 2.

\section{Racecadotril versus placebo \\ Efficacy}

Three studies with 642 participants presented data on the primary outcome, duration of diarrhoeal symptoms. Meta-analysis showed significantly shorter duration of diarrhoeal symptoms in patients in the racecadotril group compared with patients receiving placebo or no intervention (MD $-53.48 \mathrm{~h}, 95 \% \mathrm{CI}-65.64$ to -41.33 , figure 2 ). A sensitivity analysis with the fixed-effects model did not change the result. In the other studies the data were not reported in a manner that allowed inclusion within this meta-analysis.

For secondary outcomes, studies reported differently based on the setting of patients. Meta-analysis of two studies with 405 inpatient participants showed significantly less stool output in the first $48 \mathrm{~h}$ of treatment in the racecadotril group compared with placebo or no intervention (MD $-150 \mathrm{~g} / \mathrm{kg}, 95 \% \mathrm{CI}-291$ to -8.9 , figure 3 ). This result showed significant heterogeneity, but was still significant using a fixed-effects model. Meta-analysis of three studies with 422 outpatient participants showed less stool output per day at $48 \mathrm{~h}$ in the racecadotril group, although this was not significant (MD -2.59 stools per day, $95 \%$ CI -5.26 to 0.08 , figure 4 ). There was significant heterogeneity, with the result showing a significantly significant difference favouring racecadotril when using the fixed-effects model (MD -2.57 stools per day, $95 \% \mathrm{CI}-3.03$ to -2.30 ).
Further subgroup analyses were planned but could not be performed due to limited data within the included studies.

Safety

Meta-analysis of five studies with 949 participants showed no significant difference in reported adverse events between racecadotril and placebo (OR 0.99, 95\% CI 0.73 to 1.34 , figure 5). Studies totalled events, but did not give a specific breakdown of specific events. Events reported included vomiting, abdominal distension, abdominal pain, rashes and one case of transient raised transaminases (racecadotril).

No serious adverse events were reported in any study. Funnel plots of these analyses were symmetrical.

\section{Racecadotril versus loperamide}

As there was only one study, no meta-analysis was performed.

\section{Efficacy}

The duration of diarrhoeal symptoms was reported as similar between the two groups (mean (SE) 10.7 (1.7) h with racecadotril vs 8.8 (2.3) h with loperamide).

\section{Safety}

The incidence of adverse events was lower with racecadotril than with loperamide and significantly more patients on loperamide had constipation.

\section{Racecadotril versus kaolin/pectin}

As there was only one study, no meta-analysis was performed.

\section{Efficacy}

The number of diarrhoeal episodes was reported as significantly less in the racecadotril group (mean total of 18.96 episodes with kaolin/pectin vs 8.88 with racecadotril).

Safety

Adverse events data were not presented.

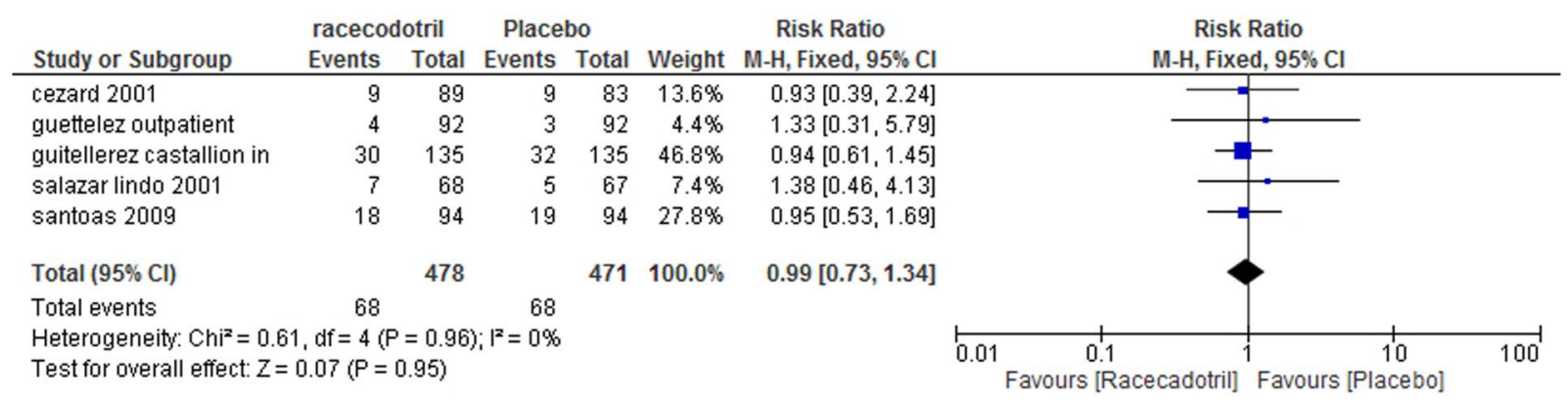

Figure 5 Forest plot of total reported adverse events, racecadotril versus placebo. 


\section{DISCUSSION}

With the new licence for racecadotril in the UK allowing use in children under 4 years of age, it is important to clearly establish the evidence base regarding its efficacy and safety. The evidence synthesised suggests that the addition of racecadotril to ORS can reduce the duration of symptoms as well as the number and volume of stools passed during the illness. When these results are considered in a clinical context they do appear significant, with a reduction of symptoms of $>2$ days and $130 \mathrm{~mL} / \mathrm{kg}$ of stool loss per day likely to have a significant impact for both the child and parent. Adverse events in children receiving racecadotril were not statistically significantly different from placebo, suggesting appropriate safety. Heterogeneity in reporting did not allow any other outcomes to be analysed.

It must be noted that the quality of the evidence base was less than optimum, with several studies having significant areas where risk of bias was of concern. Clinical heterogeneity in terms of the context and countries of studies, as well as methodological heterogeneity in the outcomes measured, age of participants and time and setting of recruitment, further weaken the evidence base, so it is suggested that these are considered when judging the strength of the findings. Additionally, it is worth noting that there have been no studies completed in the UK.

In examining the introduction of a new treatment such as this within the UK, there is more to consider than simply efficacy and safety. Clarifying the evidence base allows those considering the use of this agent to begin to evaluate these other aspects. A recent study has sought to complete a UK-centred cost analysis which suggests that racecadotril is less costly than ORS alone for the treatment of children with acute diarrhoea. ${ }^{21}$ However, such analysis does not consider the context-specific issues that will be key to consider when making local decisions about the introduction of such an agent, including the time of use within a diarrhoeal illness and whether initiation takes place in primary or secondary care. Additionally, there are no studies that consider qualitative outcomes that may be key in deciding whether to employ such an adjunct agent. Considering how the use of racecadotril changes the impact of such illness on patients, parents and families would further inform commissioning bodies and wider stakeholders in the role of this agent.

\section{CONCLUSIONS}

There is evidence from this review that racecadotril is more effective than placebo or no intervention in reducing the duration of illness and stool output in children with acute diarrhoea and appears to be safe. The overall quality of the evidence and strength of these conclusions is limited due to sparse data, heterogeneity and risk of bias in the studies. Further work is suggested to consider the qualitative impact on patients and families within the UK of the use of such an agent as an adjunct therapy for acute diarrhoeal illness.

Contributors MG conceived the study and led the study and writing of the manuscript. AA contributed and reviewed the protocol and writing of the manuscript and finalised the final draft, as well as co-searching and extracting the data.

Competing interests MG has received travel and educational grants from various companies including Danone, Abbott, Warner Chilcott, Casen Fleet, Norgine, Ferring and Vifor. These companies had no involvement in the carrying out or reporting of this or any other research works. Abbott gave a travel grant to present these results at DDW in 2014 in USA but had no involvement in the planning, execution or writing of this or any studies. AA has nothing to declare.

Provenance and peer review Not commissioned; externally peer reviewed.

Data sharing statement For the study protocol and any further data, please email morris@betterprescribing.com.
Open Access This is an Open Access article distributed in accordance with the Creative Commons Attribution Non Commercial (CC BY-NC 4.0) license, which permits others to distribute, remix, adapt, build upon this work non-commercially, and license their derivative works on different terms, provided the original work is properly cited and the use is non-commercial. See: http://creativecommons.org/ licenses/by-nc/4.0/

\section{REFERENCES}

1 Sands R, Shanmugavadivel D, Stephenson T, et al. Medical problems presenting to paediatric emergency departments: 10 years on. Emerg Med J 2012;29: 379-82.

2 Gill PJ, Goldacre MJ, Mant D, et al. Increase in emergency admissions to hospital for children aged under 15 in England, 1999-2010: national database analysis. Arch Dis Child 2013;98:328-34.

3 Nataro JP. Diarrhea among children in developing countries. Adv Exp Med Biol 2013;764:73-80

4 Bruzzese E, Lo Vecchio A, Guarino A. Hospital management of children with acute gastroenteritis. Curr Opin Gastroenterol 2013;29:23-30.

5 Freedman SB, Sivabalasundaram V, Bohn V, et al. The treatment of pediatric gastroenteritis: a comparative analysis of pediatric emergency physicians' practice patterns. Acad Emerg Med 2011;18:38-45.

6 Riddle MS, Arnold S, Tribble DR. Effect of adjunctive loperamide in combination with antibiotics on treatment outcomes in traveler's diarrhea: a systematic review and meta-analysis. Clin Infect Dis 2008:47:1007-14.

7 Eberlin M, Mück T, Michel MC. A comprehensive review of the pharmacodynamics, pharmacokinetics, and clinical effects of the neutral endopeptidase inhibitor racecadotril. Front Pharmacol 2012;3:93

8 Szajewska H, Ruszczyński M, Chmielewska A, et al. Systematic review: racecadotril in the treatment of acute diarrhoea in children. Aliment Pharmacol Ther 2007:26:807-13.

9 Lehert P, Chéron G, Calatayud GA, et al. Racecadotril for childhood gastroenteritis: an individual patient data meta-analysis. Dig Liver Dis 2011;43:707-13.

10 Pitkin RM, Branagan MA, Burmeister LF. Accuracy of data in abstracts of published research articles. JAMA 1999:281:1110-1.

11 Higgins JPT, Altman DG, Sterne JAC. Assessing risk of bias in included studies. In: Higgins JPT, Green S, eds. Cochrane Handbook for Systematic Reviews of Interventions Version 5.1.0 (updated March 2011). Chapter 8. The Cochrane Collaboration, 2011. http://http://www.cochrane-handbook.org

12 Higgins JP, Thompson SG, Deeks JJ, et al. Measuring inconsistency in meta-analyses. BMJ 2003;327(7414):557-60

13 Alam NH, Ashraf $\mathrm{H}$, Khan WA, et al. Efficacy and tolerability of racecadotril in the treatment of cholera in adults: a double blind, randomised, controlled clinical trial. Gut 2003;52:1419-23.

14 Alvarez Calatayud G, Pinel G, et al. Efectividad de racecadotrilo en el tratamiento de la gastroenteritis aguda. Acta Pediatr Esp 2009;67:177-22. http://static. vademecum.es/documentos/evidencia/tiorfan/AlvarezCalatayud.AnPediatr.pdf

15 Cojocaru B, Bocquet N, Timsit S, et al. Effet du racécadotril sur le recours aux soins dans le traitement des diarrhées aiguës du nourrisson et de l'enfant. Arch Pédiatr 2002;8:774-9.

16 Guarino A, Dupont C, Gorelov AV, et al. The management of acute diarrhea in children in developed and developing areas: from evidence base to clinical practice. Expert Opin Pharmacother 2012;13:17-26.

17 Huighebaert $\mathrm{S}$, Awouters F, Tytgat GNJ. Racecadotril versus loperamide: antidiarrheal research revisited. Dig Dis Sci 2003:48:239-50.

18 Mehta S, Khandelwal PD, Jain VK, et al. A comparative study of racecadotril and single dose octreotide as an anti-secretory agent in acute infective diarrhoea. J Assoc Physicians India 2012;60:12-15.

19 Pieścik-Lech $M$, Shamir R, Guarino A, et al. Review article: the management of acute gastroenteritis in children. Aliment Pharmacol Ther 2013:37:289-303.

20 Rao SG. Racecadotril (acetorphan) in the treatment of acute watery diarrhoea in children. J Indian Med Assoc 2002;100:530.

21 Rautenberg TA, Zerwes U, Foerster D, et al. Evaluating the cost utility of racecadotril for the treatment of acute watery diarrhea in children: the RAWD model. Clinicoecon Outcomes Res 2012:4:109-16.

22 Tebruegge M. Racecadotril did not improve diarrhoeal symptoms in children with moderate acute gastroenteritis. Arch Dis Child Educ Pract Ed 2010;95:197

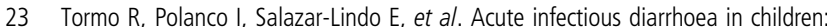
new insights in antisecretory treatment with racecadotril. Acta Paediatr 2008:97:1008-15.

24 Savitha MR. Racecadotrial — a novel drug for treatment of acute watery diarrhoea in Indian children. Karnataka Pedicon 2005-Conference Abstracts. Pediatric Oncall [serial online]; 2006 (cited 1 January 2006):3. http://www.pediatriconcall.com/ fordoctor/Conferenceabstracts/racecadotrial.asp

25 Cézard JP, Duhamel JF, Meyer $\mathrm{M}$, et al. Efficacy and tolerability of racecadotril in acute diarrhea in children. Gastroenterology 2001;120:799-805. 
26 Gutierrez Castrellon P, Polanco Allue I, Salazar Lindo E. An evidence based Iberic-Latin American guideline for acute gastroenteritis management in infants and prescholars (Manejo de la gastroenteritis aguda en menores de 5 anos: un enfoque basado en la evidencia. Guia de practica clinical Ibero-Latinoamericana. An Pediatr (Barcelona) 2010;71:e1-220.e20.

27 Salazar-Lindo E, Santisteban-Ponce J, Chea-Woo E, et al. Racecadotril in the treatment of acute watery diarrhoea in children. N Engl J Med 2000;343:463-7.
28 Santos M, Marañón R, Miguez C, et al. Use of racecadotril as outpatient treatment for acute gastroenteritis: a prospective, randomised, parallel study. J Pediatr 2009;155:62-7.

29 Melendez Garcia JM, Rodriguez JT. Racecadotril en el tratamiento de la diarrea aguda en ninos. Revista de la Facultad de Medicina (Guatemala) 2007:4:25-8.

30 Turck D, Berard H, Fretault N, et al. Comparison of racecadotril and loperamide in children with acute diarrhoea. Aliment Pharmacol Ther 1999;13:27-32. 